\title{
Modulator Effects of Interleukin- $1 \beta$ and Tumor Necrosis Factor- $\alpha$ on AMPA-Induced Excitotoxicity in Mouse Organotypic Hippocampal Slice Cultures
}

\author{
Liliana Bernardino, ${ }^{2}$ Sara Xapelli, ${ }^{2}$ Ana P. Silva, ${ }^{2}$ Birthe Jakobsen, ${ }^{1}$ Frantz R. Poulsen, ${ }^{1}$ Catarina R. Oliveira, ${ }^{2}$ \\ Annamaria Vezzani, ${ }^{3}$ João 0. Malva, ${ }^{2}$ and Jens Zimmer $^{1}$ \\ ${ }^{1}$ Anatomy and Neurobiology, Institute of Medical Biology, University of Southern Denmark, DK-5000 Odense C, Denmark, ${ }^{2}$ Center for Neuroscience and \\ Cell Biology, Institute of Biochemistry, Faculty of Medicine, University of Coimbra, 3004-504 Coimbra, Portugal, and ${ }^{3}$ Laboratory of Experimental \\ Neurology, Department of Neuroscience, Mario Negri Institute for Pharmacological Research, 20157 Milano, Italy
}

The inflammatory cytokines interleukin- $1 \beta$ and tumor necrosis factor- $\alpha$ (TNF- $\alpha$ ) have been identified as mediators of several forms of neurodegeneration in the brain. However, they can produce either deleterious or beneficial effects on neuronal function. We investigated the effects of these cytokines on neuronal death caused by exposure of mouse organotypic hippocampal slice cultures to toxic concentrations of AMPA. Either potentiation of excitotoxicity or neuroprotection was observed, depending on the concentration of the cytokines and the timing of exposure. A relatively high concentration of mouse recombinant TNF- $\alpha(10 \mathrm{ng} / \mathrm{ml})$ enhanced excitotoxicity when the cultures were simultaneously exposed to AMPA and to this cytokine. Decreasing the concentration of TNF- $\alpha$ to $1 \mathrm{ng} / \mathrm{ml}$ resulted in neuroprotection against AMPA-induced neuronal death independently on the application protocol. By using TNF- $\alpha$ receptor (TNFR) knock-out mice, we demonstrated that the potentiation of AMPA-induced toxicity by TNF- $\alpha$ involves TNF receptor-1, whereas the neuroprotective effect is mediated by TNF receptor-2. AMPA exposure was associated with activation and proliferation of microglia as assessed by macrophage antigen-1 and bromodeoxyuridine immunohistochemistry, suggesting a functional recruitment of cytokineproducing cells at sites of neurodegeneration. Together, these findings are relevant for understanding the role of proinflammatory cytokines and microglia activation in acute and chronic excitotoxic conditions.

Key words: glutamate; cytokines; inflammation; neuroprotection; neurodegeneration; microglia

\section{Introduction}

Cytokines are involved in immune responses and in various CNS events (Allan and Rothwell, 2001; Beattie, 2004). Cytokines are barely detectable in the CNS under physiological conditions, but they become rapidly upregulated by pathological events, like ischemia (Minami et al., 1992; Wang et al., 1997), excitotoxicity (Minami et al., 1991), lipopolysaccharide injection (Gabellec et al., 1995), or viral infection (Marquette et al., 1996). In this respect, two of the best-studied cytokines are interleukin (IL)-1 $\beta$ and tumor necrosis factor- $\alpha$ (TNF- $\alpha$ ) (Rothwell and Luheshi, 2000; Allan and Rothwell, 2001; Kunkler et al., 2004).

Increased expression of IL- $1 \beta$ mRNA and protein in the brain has been reported in response to several forms of neuronal dam-

\footnotetext{
Received Dec. 21, 2004; revised May 31, 2005; accepted May 31, 2005.

This work was supported by the Foundation for Science and Technology, Portugal, and FEDER (Projects SFRH/ BD/14163/2003, SFRH/BD/12731/2003, POCT/NSE/46848/2002, and POCTI/SAU-NEU/58492/2004) and by grants from the Novo Nordisk Foundation, the Danish Medical Research Council, the European Union FP5 program (QLK3(T-2001-00407), and Fondazione Mariani Onlus (R-05-46) to A.V. LY303070 was a kind gift from Lilly Research Laboratories. The technical help of Dorte Bramsen, Inge Nielsen, Maibritt Vang Damm, Karen Rich, and Rand Godskesen is gratefully acknowledged.

Correspondence should be addressed to João 0. Malva, Center for Neuroscience and Cell Biology, Institute of Biochemistry, Faculty of Medicine, University of Coimbra, Rua Larga, 3004-504 Coimbra, Portugal. E-mail: jomalva@fmed.uc.pt.

DOI:10.1523/JNEUROSCI.1510-05.2005

Copyright $\odot 2005$ Society for Neuroscience $\quad$ 0270-6474/05/256734-11\$15.00/0
}

age (Minami et al., 1990, 1992; Taupin et al., 1993; Yabuuchi et al., 1993; Wang et al., 1994; De Simoni et al., 2000), and inhibition of endogenous IL- $1 \beta$ in vivo, by administration of recombinant IL- $1 \beta$ receptor antagonist (IL-1ra), reduces injury caused by excitotoxicity, trauma, or ischemia (Loddick and Rothwell, 1996; Loddick et al., 1996; Hara et al., 1997). However, IL-1 $\beta$ can increase also the synthesis of neurotrophic factors and inhibitory peptides, suggesting that it might mediate beneficial effects on neurons (Rivera et al., 1994; Miyachi et al., 2001).

TNF- $\alpha$ is a pleiotropic peptide that binds to specific receptors, expressed by both glia and neurons (Wolvers et al., 1993). Two different TNF receptors (TNFRs) (TNFR1 or p55 and TNFR2 or p75) have been identified (Beutler and van Huffel, 1994), and they have been shown to mediate different cellular responses using distinct, although partially overlapping, pathways (Tartaglia et al., 1991; Downen et al., 1999; Sullivan et al., 1999). Several lines of evidence have implicated TNF- $\alpha$ as a crucial mediator of neuronal cell death in focal cerebral ischemia and traumatic brain injury (Meistrell et al., 1997; Nawashiro et al., 1997a; Scherbel et al., 1999; Sullivan et al., 1999; Kunkler et al., 2004). However, other findings support a neuroprotective role of this cytokine. In particular, knock-out (KO) mice lacking both TNF receptors or TNFR1 receptors only (Bruce et al., 1996; Gary et al., 1998) show exacerbated ischemic and excitotoxic brain damage. Concerning 
possible signal transduction mechanisms, TNF- $\alpha$ plays a neuroprotective role in ischemic tolerance (Nawashiro et al., 1997b; Zimmermann et al., 2001) and in glucose deprivation-induced injury, and these effects seem to involve attenuation of the elevation of intracellular $\mathrm{Ca}^{2+}$ (Cheng et al., 1994). Other potential mechanisms of TNF- $\alpha$-mediated neuroprotection include stimulation of antioxidant pathways (Wilde et al., 2000) and enhanced expression of manganese superoxide dismutase or calbindin (Cheng et al., 1994; Barger et al., 1995; Mattson et al., 1997).

In this study, we used organotypic mouse hippocampal slice cultures to investigate the putative roles of TNF- $\alpha$ and IL- $1 \beta$ in glutamate receptor-mediated neurodegeneration, and under which circumstances, neurotoxic versus neuroprotective effects occur. Given that microglial cells are a major source of endogenous CNS cytokine production (De et al., 2003), microglia activation and proliferation, in relation to the excitotoxic neuronal cell death mediated by glutamate receptor activation, were also assessed.

\section{Materials and Methods}

Organotypic hippocampal slice cultures. Hippocampal slice cultures were prepared from 6- to 8-d-old wild-type (WT) or TNFR KO C57BL/6 mice, according to the interface culture method (Stoppini et al., 1991), as modified by Kristensen et al. (1999) and Noraberg et al. (1999). C57BL/6 mice was the strain used to generate homozygous TNFR $1^{-1-}$, TNFR $^{-1-}$, or TNFR1 $1^{-1}$ $-/$ TNFR2 $^{-/-}$doubly deficient mice. Generation and detailed characterization of these TNFR-deficient mice were reported previously (Peschon et al., 1998). Briefly, and in accordance with ethically approved standard procedures (Danish and European Community guidelines for the use of animals in laboratory), mice were killed by decapitation, the brains were removed under sterile conditions, and the two hippocampi were isolated and cut in transverse sections at $350 \mu \mathrm{m}$ using a Mcllwain tissue chopper. Individual slices were released of excess tissue and placed in ice-cold Gey's balanced salt solution (GBSS; Biological Industries, Kibbutz Beit Haemek, Israel) with 25 mM D-glucose (Merck, Darmstadt, Germany) before placed on porous $(0.4 \mu \mathrm{m})$ insert membranes (Millipore, Bedford, MA), with six slices on each membrane, and transferred to six-well culture trays (Corning Costar, Corning, NY). Each well contained $1 \mathrm{ml}$ of culture medium composed of $50 \%$ Opti-MEM, 25\% heat-inactivated horse serum, and 25\% HBSS (all from Invitrogen, Paisley, UK) and supplemented with D-glucose to a final concentration of $25 \mathrm{~mm}$. The cultures were then placed in an incubator with $5 \%$ $\mathrm{CO}_{2}$ and $95 \%$ atmospheric air at $33^{\circ} \mathrm{C}$ with medium change twice each week for the following 2-3 weeks. No antibiotics or antimitotics were used at any stage. At the start of experiments, the culture medium was replaced with $1 \mathrm{ml}$ of chemically defined, serum-free neurobasal medium (Invitrogen) with $1 \mathrm{~mm}$ L-glutamine (Invitrogen), and B27 supplement (Invitrogen), and the incubator temperature was raised to $36^{\circ} \mathrm{C}$. The initial medium and temperature conditions were used to improve the long-term survival and growth conditions of the cultures, whereas the changes of temperature and medium, during the experiments, served to adapt the cultures to experimental conditions.

Determination of neuronal damage by propidium iodide uptake. Spontaneous and induced neuronal cell death in the slice cultures was assessed by monitoring the culture uptake of the fluorescent dye propidium iodide (PI) [3,8-diamino-5-(3-(diethylmethylamino)propyl)-6-phenyl phenanthridinium diiodide; Sigma, St. Louis, MO], a method routinely used and validated in our laboratories (Kristensen et al., 1999, 2001; Noraberg et al., 1999; Silva et al., 2003). PI is a stable fluorescent dye absorbing blue-green light (493 nm) emitting red fluorescence $(630 \mathrm{~nm})$. As a polar substance, it only enters dead or dying cells with a damaged or leaky cell membrane, interacting with DNA to yield a bright red fluorescence. PI is nontoxic to neurons (Hsu et al., 1994; Kristensen et al., 2001) and has been used as an indicator of neuronal membrane integrity (Pozzo Miller et al., 1994) and cell damage (Vornov et al., 1991; Hsu et al., 1994). Three hours before exposure to AMPA and/or other compounds, $2 \mu \mathrm{M}$ PI was added to the medium for determination of basal cellular uptake (see Fig. 1), and the same concentration of PI was always added at all subsequent medium changes during the experimental period. Cellular uptake of PI was recorded by fluorescence microscopy [Olympus (Ballerup, Denmark) IMT-2, 4X (Slan FL2)] using a digital camera (Sensys KAF 1400 G2; Photometrics, Tucson, AZ) with 0.75 s of exposure time. After exposure of the cultures to the drugs, digital fluorescent micrographs were taken at different points and used for densitometry measurements of the PI uptake in the dentate granule cell layer (DG) and in the CA3 and CA1 pyramidal cell layers. This was done by delineating the different subfields using NIH Image 1.62 analysis software.

Dose-response study of AMPA-induced excitotoxicity. Excitotoxic effects of AMPA were monitored by PI uptake and measured densitometrically in the entire slice culture as well as in the individual subfields. For determination of half-maximal excitotoxic concentrations ( $\mathrm{EC}_{50}$ values), 3-week-old slice cultures were exposed for $24 \mathrm{~h}$ to doses of 1-30 $\mu \mathrm{M}$ AMPA (Tocris Cookson, Bristol, UK) and then returned to neurobasal medium without drugs for an additional $24 \mathrm{~h}$ (see Fig. $1 \mathrm{~A}$ ). The fluorescent micrographs of the PI uptake were taken before the exposure to AMPA (day 0), after $24 \mathrm{~h}$ (day 1 ) and $48 \mathrm{~h}$ (day 2) of exposure, and at the end of the additional recovery period (day 3 ). Control cultures were not exposed to any drugs. The selective involvement of AMPA receptors in neuronal death was investigated by coexposing one group of slice cultures to the estimated $\mathrm{EC}_{50}$ value of $8 \mu \mathrm{M}$ AMPA, with $15 \mu \mathrm{M}(-)-1-(4-$ aminophenyl)-3-methylcarbamyl-4-methyl-3,4-dihydro-7,8-methylenedioxy-5H-2,3-benzodiazepine (LY303070), a selective noncompetitive AMPA receptor antagonist (kind gift from Lilly Research Laboratories, Indianapolis, IN). The basal PI uptake at $0 \mathrm{~d}$ was subtracted from the values recorded at 1,2 , and $3 \mathrm{~d}$ in each experimental condition.

Cytokine exposure. The effects of cytokines on AMPA-mediated neuronal cell death were studied by exposing WT slice cultures to mouse recombinant IL-1 $\beta$ (R \& D Systems, London, UK) or mouse or human recombinant TNF- $\alpha$ (mouse sequence; R \& D Systems; human sequence, Abingdon Peprotech, London, UK) using the following temporal sequences: preincubation for $24 \mathrm{~h}$ only before adding $8 \mu \mathrm{M}$ AMPA, preincubation plus coincubation with AMPA, or only coincubation with AMPA (see Fig. 1B) (Wilde et al., 2000; Pringle et al., 2001). The same protocols were used to study the effect of anti-TNF- $\alpha$ antibody (Upstate Biotechnology, Lake Placid, NY) and IL-1ra (R \& D Systems). AntiTNF- $\alpha$ antibody was used at $81 \mu \mathrm{g} / \mathrm{ml}$ or $162 \mu \mathrm{g} / \mathrm{ml}$ to neutralize the biological effects of $1 \mathrm{ng} / \mathrm{ml}$ or $10 \mathrm{ng} / \mathrm{ml} \mathrm{TNF}-\alpha$, respectively (in agreement with the instruction of the supplier), whereas IL-1 ra was given in a ratio of 10:1 to IL-1 $\beta$ concentrations (Pringle et al., 2001). We also performed a dose-response study $(0.3-30 \mathrm{ng} / \mathrm{ml})$ for either cytokines, applying the experimental protocol that allowed us to observe neurotoxic and/or neuroprotective effects against AMPA-mediated cell death. Therefore, slices were preincubated with TNF- $\alpha$ for $24 \mathrm{~h}$ plus coincubation with AMPA for additional $24 \mathrm{~h}$. The selective involvement of individual TNF- $\alpha$ receptor subtypes in neuronal death or survival was studied by exposing TNFR1 or TNFR2 KO hippocampal slices to TNF- $\alpha$ and AMPA using the same experimental protocol, which provided protective or toxic effects in both CA1 and CA3 subfields.

All experiments included a separated series of control cultures not subjected to AMPA, TNF- $\alpha$, IL- $1 \beta$, anti-TNF- $\alpha$ antibody, or IL-1ra. Fluorescent micrographs of the PI uptake were taken before the exposure to drugs ( $0 \mathrm{~d}$; basal uptake), at $24 \mathrm{~h}$ and $48 \mathrm{~h}$ after the exposure to drugs ( 1 and $2 \mathrm{~d}$, respectively), and after an additional $24 \mathrm{~h}$ recovery period in neurobasal medium $(3 \mathrm{~d})$. The PI uptake recorded at $0 \mathrm{~d}$ was subtracted from the values at 1,2 , and $3 \mathrm{~d}$. To assess the effects of treatments, we used the PI uptake values obtained at $2 \mathrm{~d}$ (see Fig. $1 B$ ).

Cell proliferation studies. For detection of cell proliferation, 5-bromo2'-deoxyuridine (BrdU) (Research Diagnostic, Flanders, NJ) was added to the medium for incorporation in and subsequent visualization of dividing cells. Slices were exposed to $3 \mu \mathrm{M}$ BrdU for $48 \mathrm{~h}$ (from 1 to $3 \mathrm{~d}$; see above) and followed by change to normal medium. To investigate the effect of AMPA-induced excitotoxicity on cell proliferation, the cultures were exposed for $24 \mathrm{~h}$ to AMPA and then fixed in paraformaldehyde immediately or after a $4 \mathrm{~d}$ recovery period in a medium lacking AMPA.

Immunohistochemical staining for markers of microglial cells and cell proliferation. For visualization of microglial cells and their morphological changes, cryostat sections were stained immunohistochemically using 
A
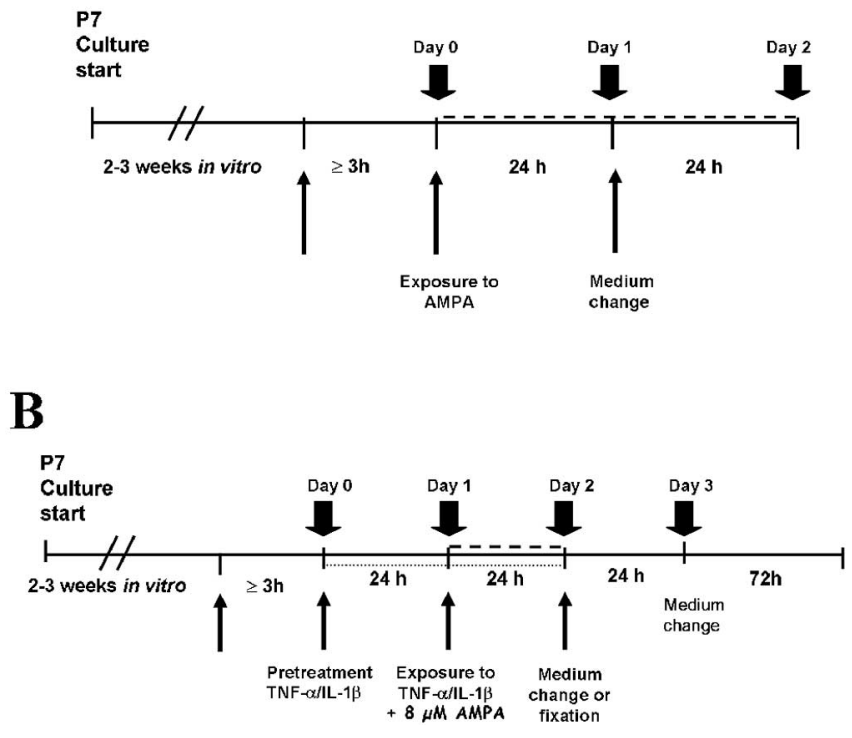

Figure 1. Schematic representation of the protocols used for studying the excitotoxic effects of AMPA ( $\boldsymbol{A}$ ) and the effects of TNF- $\alpha$ and IL- $1 \beta$ on AMPA-induced neuronal cell death $(\boldsymbol{B})$ in organotypic hippocampal slice cultures derived from postnatal day 7 C57BL/6 mice. Large arrows, Recordings of PI uptake by photography; small arrows, addition of PI to the medium; dashed lines, exposure to AMPA.

the anti-macrophage antigen-1 (Mac-1) antibody, which labels resting and activated microglia cells (Perry et al., 1985). For histological processing and immunohistochemical staining, control cultures and cultures exposed to AMPA were fixed by immersion in paraformaldehyde for 30 min, cryoprotected in $20 \%$ sucrose, stored at $4^{\circ} \mathrm{C}$, and used for subsequent cryostat sectioning (at $20 \mu \mathrm{m}$ ) and staining. Sections were stored at $-20^{\circ} \mathrm{C}$ until additional processing.

After thawing at room temperature (RT), the sections were rinsed in $0.1 \mathrm{~m}$ Tris-buffered saline (TBS), $\mathrm{pH} 7.4$, with $1 \%$ Triton X-100, treated with $10 \%$ fetal bovine serum (FBS) for $30 \mathrm{~min}$ to reduce unspecific labeling, and incubated for $24 \mathrm{~h}$ at $4^{\circ} \mathrm{C}$ with primary rat anti-Mac-1 antibody (CD11b; 1:600; Serotec, Oxfordshire, UK). Thereafter, the sections were rinsed in TBS-Triton X-100 and incubated for $1 \mathrm{~h}$ at RT with a secondary biotinylated anti-rat antibody (1:200; Amersham Biosciences, Braunschweig, Germany). After an additional rinse in TBSTriton X-100, sections were incubated in horseradish peroxidase (HRP)conjugated streptavidine (1:200; Dako, Glostrup, Denmark) for $1 \mathrm{~h}$ at RT with subsequent visualization of the HRP by $3,3^{\prime}$-diaminobenzidine (Sigma).

For subsequent BrdU staining, the sections (previously stained for the microglial marker) were rinsed with TBS and then washed in $2 \times$ sodium chloride/sodium citrate $(20 \times$ SSC stock containing $3.0 \mathrm{~m}$ sodium chloride and $0.3 \mathrm{~m}$ sodium citrate, $\mathrm{pH} 7.0$ ) for $15 \mathrm{~min}$. To enhance the immunohistochemical detection of $\mathrm{BrdU}$, the sections were treated with $49 \%$ formamide (Merck, Darmstadt, Germany) in $2 \times$ SSC at $60^{\circ} \mathrm{C}$ for $2 \mathrm{~h}$. This was followed by an additional brief wash in $2 \times$ SSC and incubation in $2 \mathrm{~N} \mathrm{HCl}$ in $\mathrm{TBS}$ at $37^{\circ} \mathrm{C}$ for $30 \mathrm{~min}$. After $10 \mathrm{~min}$ of incubation in $0.1 \mathrm{~m}$ sodium borate buffer, $\mathrm{pH} 8.5$, the sections were washed in TBS for $15 \mathrm{~min}$ and TBS-Triton X-100 for $45 \mathrm{~min}$. Sections were then incubated with $10 \% \mathrm{FBS}$ in TBS for $30 \mathrm{~min}$ at RT and then overnight at $4^{\circ} \mathrm{C}$ in sheep anti-BrdU (1:1000; Research Diagnostics) in 10\% FBS. After a rinse in TBS-Triton X-100, sections were incubated for $1 \mathrm{~h}$ at RT with secondary alkaline-phosphatase (AP)-conjugated anti-rat (1:200; Sigma), rinsed in TBS, and incubated in Tris/ $\mathrm{HCl}, \mathrm{pH} 9.5$, for $10 \mathrm{~min}$. The AP reaction was visualized with nitro blue tetrazolium/5-bromo-4chloro-3-indolyl phosphate/Levamisole (all from Sigma).

The sections were finally rinsed in water, dehydrated in acetone, and mounted with a coverslip in Aquatex (Vedbaek, Denmark). Primary
A
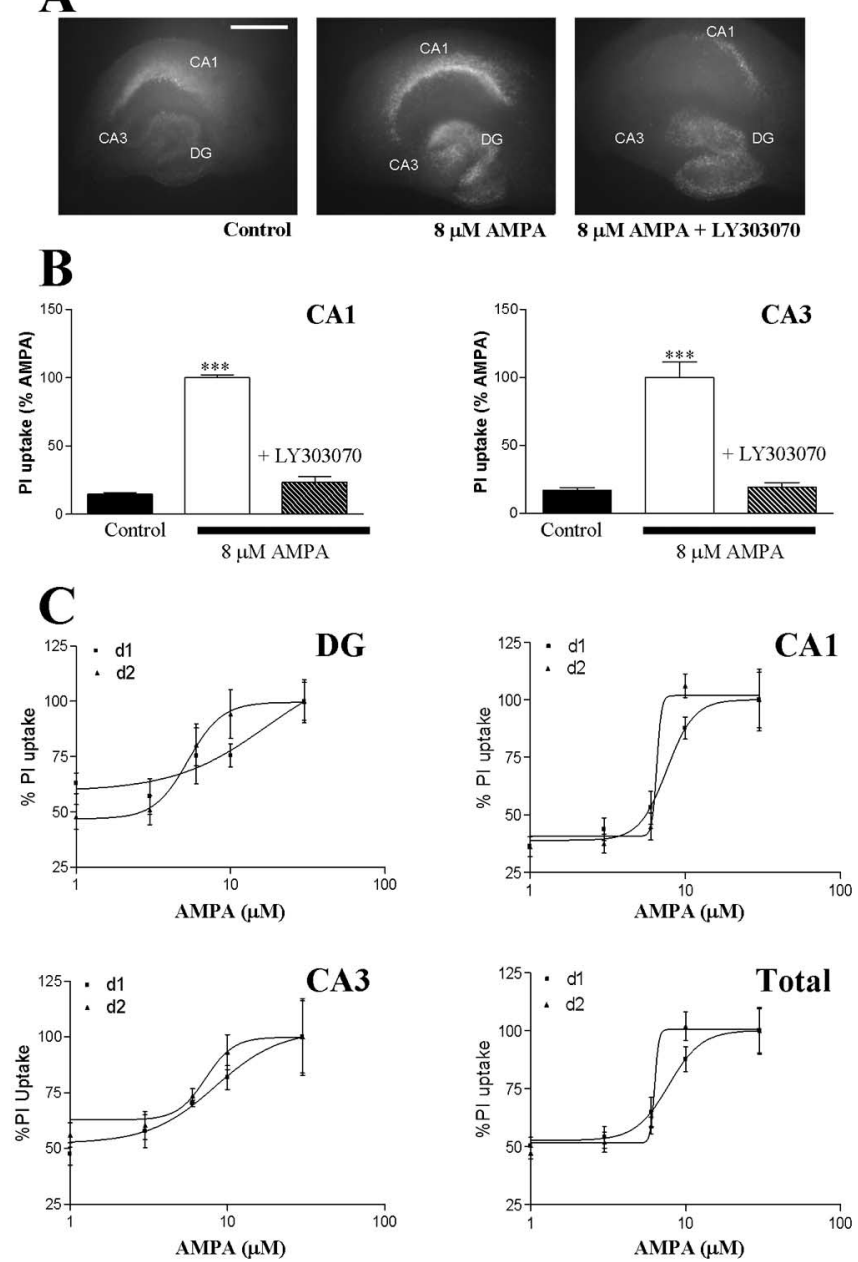

Figure 2. AMPA-induced excitotoxicity in organotypic hippocampal slice cultures of mice. $A$, Fluorescence photomicrographs of PI uptake at day 1 in representative control hippocampal slice cultures, in cultures exposed for $24 \mathrm{~h}$ to $8 \mu \mathrm{M}$ AMPA, and in cultures coexposed to $8 \mu \mathrm{M}$ AMPA and $15 \mu \mathrm{m}$ LY303070, a selective AMPA receptor antagonist. Scale bar, $500 \mu \mathrm{m}$. $\boldsymbol{B}$, Densitometry measurements of $\mathrm{Pl}$ uptake induced by $8 \mu \mathrm{M}$ AMPA in the $C A 1$ and $C A 3$ pyramidal cell layers and blockade of this effect by $15 \mu \mathrm{m} \mathrm{LY} 303070$. The Pl uptake induced by $8 \mu \mathrm{M} \mathrm{AMPA}$ was set to $100 \%$. Data are expressed as mean \pm SEM $(n=10-69)$. ${ }^{* * *} p<0.001$ using Bonferroni's correction for comparison with control (no-drug exposure). C, Dose-response relationship for increasing concentrations of AMPA (1-30 $\mu \mathrm{M})$ and cellular Pl uptake measured in the DG, in CA1 and CA3 pyramidal cell layers, and in the whole-slice culture (total) after exposure to AMPA for $24 \mathrm{~h}$ (d1) and $48 \mathrm{~h}$ (d2). The maximal Pl uptake in each condition was set to $100 \%$. Data are the mean $\pm \operatorname{SEM}(n=7)$.

antibody omission was used to test the specificity of the immunohistochemical labeling for both Mac-1 and BrdU.

Stereological analysis. Only sections of cultures with intact hippocampal subfields were used for stereological cell counts of Mac-1, BrdU, and Mac-1 plus BrdU-positive cells. For analysis, the treatment of the various series of cultures was blinded to the observer. Counts were performed in the CA1 and CA3 subfields according to the optical dissector method using Olympus Castgrid software.

Estimates of the total number of Mac-1, BrdU, and Mac-1 plus BrdUpositive cells per culture $(N)$ were calculated using the following equation:

$N=\Sigma Q^{-}(1 / \mathrm{ssf})(1 / \mathrm{asf})(1 / \mathrm{tsf})$

where $Q^{-}$is the number of cells counted, ssf is the section sampling fraction, asf is the area sampling fraction, and tsf is the thickness sampling fraction (tsf was 1).

Using the optical dissector method, the risk of counting the same cell 


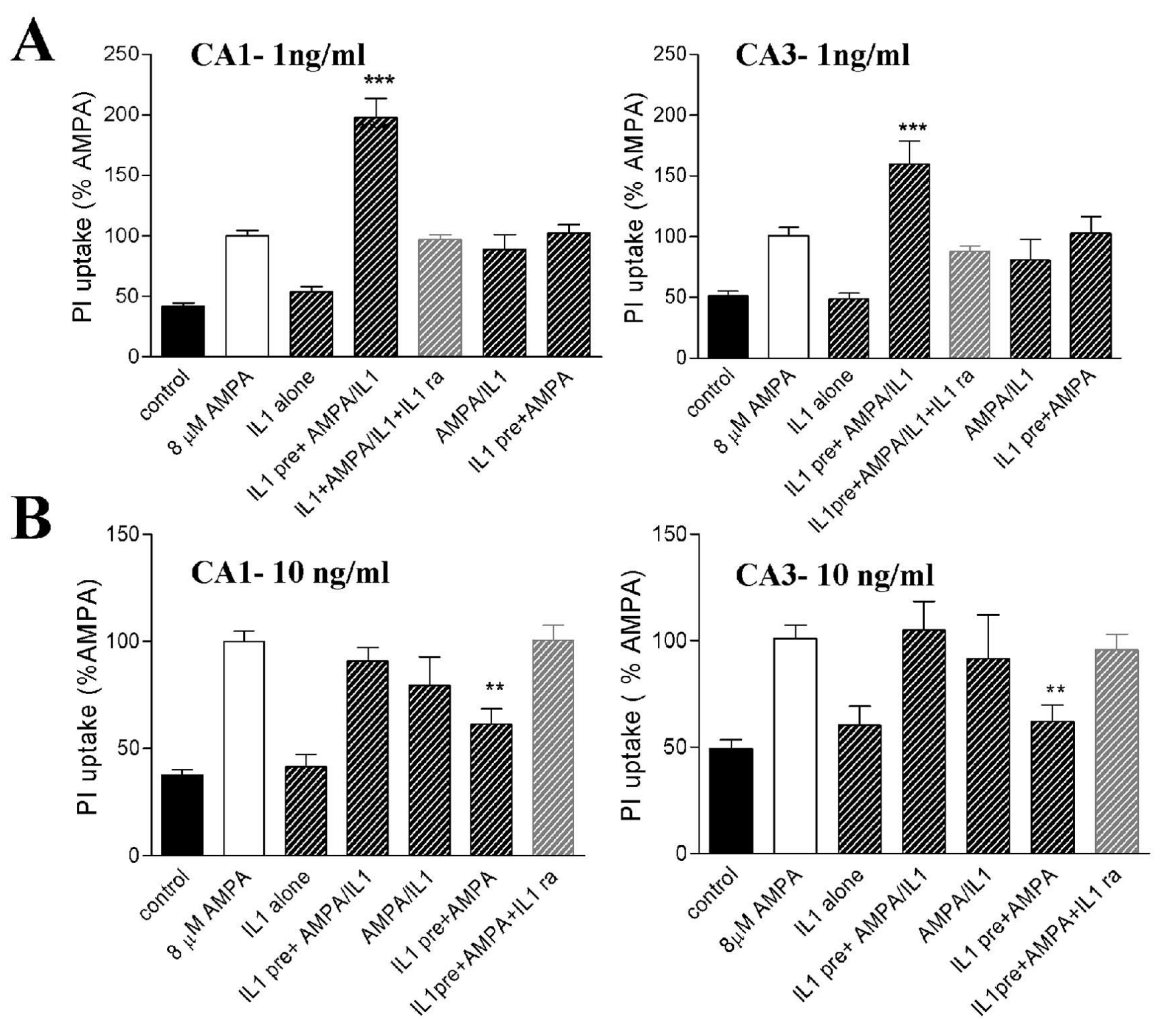

Figure 3. Modulation of AMPA-induced cell death in WT cultured mice hippocampal slices by IL-1 $\beta$. $A$, Effects of $1 \mathrm{ng} / \mathrm{ml} \mathrm{IL-1 \beta}$ on PI uptake in CA1 and CA3 pyramidal cell layers $(n=15-23)$. $B$, Effects of $10 \mathrm{ng} / \mathrm{ml}$ IL-1 $\beta$ on Pl uptake in CA 1 and CA3 pyramidal cell layers ( $n=6-21)$. In agreement with Figure 1, IL1 pre represents preincubation starting at day 0; AMPA and AMPA/IL1 represent excitotoxic insult (AMPA) or coexposure of AMPA and IL1 added at day 1. Data are mean $\pm \mathrm{SEM} .{ }^{* * *} p<0.001,{ }^{* *} p<$ 0.01 using ANOVA with Bonferroni's correction for comparison with the effect of $8 \mu \mathrm{MAMPA}(100 \%)$.

LY303070 reduced the PI uptake by $80 \%$ on average in CA1 and in CA3 (Fig. $2 A, B$ ) $(n=6)$.

\section{IL-1 $\beta$ and TNF- $\alpha$ act as biphasic modulators of AMPA-induced neurodegeneration}

The experiments described here were performed using the protocol depicted in Figure $1 B$.

\section{Low dose of IL-1 $\beta(1 \mathrm{ng} / \mathrm{ml})$}

Pre-exposure of the mouse hippocampal slice cultures to $1 \mathrm{ng} / \mathrm{ml} \mathrm{IL}-1 \beta$ for $24 \mathrm{~h}$, followed by $24 \mathrm{~h}$ of coexposure to IL- $1 \beta$ together with $8 \mu \mathrm{M}$ AMPA, significantly potentiates the AMPA-induced toxicity, with an increase in PI uptake of $197.6 \pm$ $16.2 \%(n=23)$ in CA1 and $159.6 \pm 19.1 \%$ $(n=23)$ in CA3 (Fig. 3A), compared with cultures exposed to $8 \mu \mathrm{M}$ AMPA alone $(100 \%)$. The effect of IL- $1 \beta$ was receptor mediated, because the addition of IL-1ra $(10 \mathrm{ng} / \mathrm{ml})$ blocked the IL-1 $\beta$ effect, reducing the PI uptake to $97.1 \pm 4.1 \%(n=$ $18)$ in CA1 and $87.8 \pm 4.5 \%(n=15)$ in CA3 when compared with cultures exposed to AMPA alone (Fig. 3A). No change in AMPA toxicity was observed when IL- $1 \beta$ was preincubated for $24 \mathrm{~h}$ before AMPA application but removed from the medium when AMPA was added or when IL- $1 \beta$ was added for $24 \mathrm{~h}$ together with AMPA, without preincubation. Based on a dose-response study of IL- $1 \beta$ $(0.3-30 \mathrm{ng} / \mathrm{ml})$, applying the same experi-

in two adjacent slice sections was considered to result in only minor error compared with estimation of the total number of cells (West, 1999).

Statistical analysis. The data of densitometry analysis of PI uptake were expressed as means $\pm \mathrm{SEM}$. The $\mathrm{EC}_{50}$ value for AMPA toxicity was obtained from the concentration response curve using the concentration of AMPA inducing 50\% of maximum PI uptake. Statistical significance was determined by using ANOVA, followed by Bonferroni's posttest. When evaluating the effect of cytokines on AMPA-induced excitotoxicity, the PI uptake values induced by $8 \mu \mathrm{M}$ AMPA were set to $100 \%$.

\section{Results}

\section{Dose-dependent excitotoxic effects of AMPA}

Exposure of mouse hippocampal slice cultures to increasing concentrations of AMPA, according to the experimental protocol depicted in Figure $1 A$, resulted in a concentration-dependent increase of the PI uptake in all hippocampal subfields (Fig. 2C). Basal PI uptake was very low but increased significantly after exposure to $8 \mu \mathrm{M}$ AMPA (Fig. $2 A, B$ ). The $\mathrm{EC}_{50}$ values, estimated from the sigmoid curve fit of PI uptake at day 1 were $17.2 \mu \mathrm{M}$ for the DG, $7.61 \mu \mathrm{M}$ for CA1, and $8.34 \mu \mathrm{M}$ for CA3 (Fig. 2C), thus showing minor differences in the susceptibility to damage of the three subfields. The $\mathrm{EC}_{50}$ value determined for the cultures as a whole was $7.77 \mu \mathrm{M}$ (Fig. $2 \mathrm{C}$, Total). Based on the $\mathrm{EC}_{50}$ values determined for the CA1 and CA3 subregions, we used $8 \mu \mathrm{M}$ AMPA in the subsequent experiments (Fig. 1B). The PI uptake elicited by $8 \mu \mathrm{M}$ AMPA was set to $100 \%$, for comparison with the effects evoked by the cytokines and related molecules. The addition of $15 \mu \mathrm{M}$ of the selective AMPA receptor antagonist mental protocol as above, we found that $1 \mathrm{ng} / \mathrm{ml} \mathrm{IL-1} \beta$ was the effective concentration that potentiated the AMPA-induced toxicity both in CA1 and CA3 subfields (data not shown). IL-1 $\beta$, per se, did not affect neuronal viability in any experimental condition used.

High dose of $I L-1 \beta(10 \mathrm{ng} / \mathrm{ml})$

When the dose of IL- $1 \beta$ was increased to $10 \mathrm{ng} / \mathrm{ml}$, the PI uptake induced by AMPA was reduced to $61.3 \pm 7.2 \%(n=19)$ in CA1 and $61.9 \pm 7.8 \%(n=21)$ in CA3 (Fig. $3 B)$, compared with cultures exposed to AMPA alone when IL- $1 \beta$ was applied during $24 \mathrm{~h}$ pretreatment only. However, the same dose had no effect on AMPA-induced PI uptake when applied both before and/or together with AMPA. The neuroprotective effect of pre-exposure to $10 \mathrm{ng} / \mathrm{ml} \mathrm{IL}-1 \beta$ was blocked by $100 \mathrm{ng} / \mathrm{ml} \mathrm{IL}-1 \mathrm{ra}$ in CA1 $(100.7 \pm$ $6.8 \% ; n=7)$ and in CA3 pyramidal cell layers $(95.7 \pm 7.4 \% ; n=$ 7) versus AMPA alone (Fig. $3 B$ ). Slices were also pre-exposed to increasing concentrations of IL- $1 \beta(0.3-30 \mathrm{ng} / \mathrm{ml})$ for $24 \mathrm{~h}$ followed by $24 \mathrm{~h}$ of exposure to AMPA alone. We found that 10 $\mathrm{ng} / \mathrm{ml}$ was the effective concentration to promote neuroprotection against AMPA-induced excitotoxicity both in CA1 and CA3 subfields (data not shown).

Low dose of TNF- $\alpha(1 \mathrm{ng} / \mathrm{ml})$

TNF- $\alpha(1 \mathrm{ng} / \mathrm{ml})$ was consistently neuroprotective against AMPA-induced neurodegeneration in CA1 in all incubation protocols. TNF- $\alpha$ applied for $24 \mathrm{~h}$ before AMPA reduced PI uptake to $59.1 \pm 6.3 \%(n=21)$ compared with AMPA alone. A signifi- 
cant reduction of PI uptake was also observed when TNF- $\alpha$ was applied before and together with $8 \mu \mathrm{M}$ AMPA (57.7 \pm $5.7 \% ; n=22)$ and also when applied exclusively together with AMPA (without preincubation) $(64.6 \pm 7.3 \% ; n=18)$ (Fig. 4A). This neuroprotective effect was abolished in all incubation protocols by the presence of $81 \mu \mathrm{g} / \mathrm{ml}$ of a neutralizing antibody against TNF- $\alpha$ (Fig. 4A). A neuroprotective effect of TNF- $\alpha$ against AMPA-induced toxicity was also found in CA3 but only when the slices were preincubated with the cytokine for $24 \mathrm{~h}$ before the application of AMPA. In this instance, the PI uptake was reduced to $57.9 \pm 8.3 \%$ $(n=19)$ of AMPA values when TNF- $\alpha$ was applied in the pretreatment protocol only and to $64.3 \pm 6.6 \%(n=23)$ of AMPA values when TNF- $\alpha$ was applied either before or during exposure with AMPA (Fig. 4A). These neuroprotective effects were abolished in the presence of 81 $\mu \mathrm{g} / \mathrm{ml}$ of a neutralizing antibody against TNF- $\alpha$ (Fig. 4A).

\section{High dose of TNF- $\alpha(10 \mathrm{ng} / \mathrm{ml})$}

Increasing the dose of TNF- $\alpha$ to $10 \mathrm{ng} / \mathrm{ml}$ caused an increase in AMPA-induced PI uptake, both when applied for $24 \mathrm{~h}$ before AMPA followed by coapplication of TNF- $\alpha$ and AMPA or in the absence of preincubation when directly coapplied together with AMPA. Values for PI uptake were $145.2 \pm 6.8 \%(n=30)$ in CA1 and $141.4 \pm 11.9 \%(n=30)$ in CA3 compared with PI uptake in cultures exposed to AMPA alone (Fig. $4 B$ ). The potentiation of AMPA toxicity was also significantly increased in CA1 (but not in CA3) when $10 \mathrm{ng} / \mathrm{ml}$ TNF- $\alpha$ was coapplied with AMPA but without preincubation $[138.0 \pm 6.8 \%(n=35)$ of values measured for AMPA alone]. The observed potentiating effect of TNF- $\alpha$ on AMPA-induced excitotoxicity was blocked by $162 \mu \mathrm{g} / \mathrm{ml}$ antiTNF- $\alpha$ antibody (Fig. $4 B$ ).

Application of $1 \mathrm{ng} / \mathrm{ml}$ TNF- $\alpha$ was without effect on cell viability, whereas application of $10 \mathrm{ng} / \mathrm{ml} \mathrm{TNF}-\alpha$ for $24 \mathrm{~h}$ was toxic, thus increasing the PI uptake to $179.5 \pm 15.8 \%(n=27)$ in CA1 and to $234.5 \pm 28.9 \%(n=21)$ in CA3 when compared with untreated slices (set to 100\%). This effect was abolished by $162 \mu \mathrm{g}$ of the antibody anti-TNF- $\alpha$ (data not shown).

Slices were also pre-exposed to increasing concentrations of TNF- $\alpha(0.3-30 \mathrm{ng} / \mathrm{ml})$ for $24 \mathrm{~h}$ followed by $24 \mathrm{~h}$ of coincubation with TNF- $\alpha$ and AMPA. We found that $1 \mathrm{ng} / \mathrm{ml} \mathrm{TNF-} \alpha$ was the effective concentration to induce neuroprotection (Fig. $5 A$ ), thus reducing the PI uptake induced by AMPA to $65.4 \pm 3.5 \%(n=$ $43)$ in CA1 and to $67.2 \pm 7.5 \%(n=32)$ in CA3 subfields (Fig. $5 A$ ). Moreover, we also determined that $10 \mathrm{ng} / \mathrm{ml}$ was the effective concentration for inducing neurotoxicity, thus increasing PI uptake induced by AMPA to $118.7 \pm 2.6 \%(n=61)$ in CA1 and to $139.4 \pm 5.8 \%(n=58)$ in CA3 subfields (Fig. $5 A)$. Because human recombinant TNF- $\alpha$ is known to bind to mouse TNFR1 only (Stefferl et al., 1996), we used human TNF- $\alpha$ to test whether TNFR1 was involved in mediating the enhancing effect of TNF- $\alpha$ on AMPA-induced toxicity. Human TNF- $\alpha(10 \mathrm{ng} / \mathrm{ml})$ increased
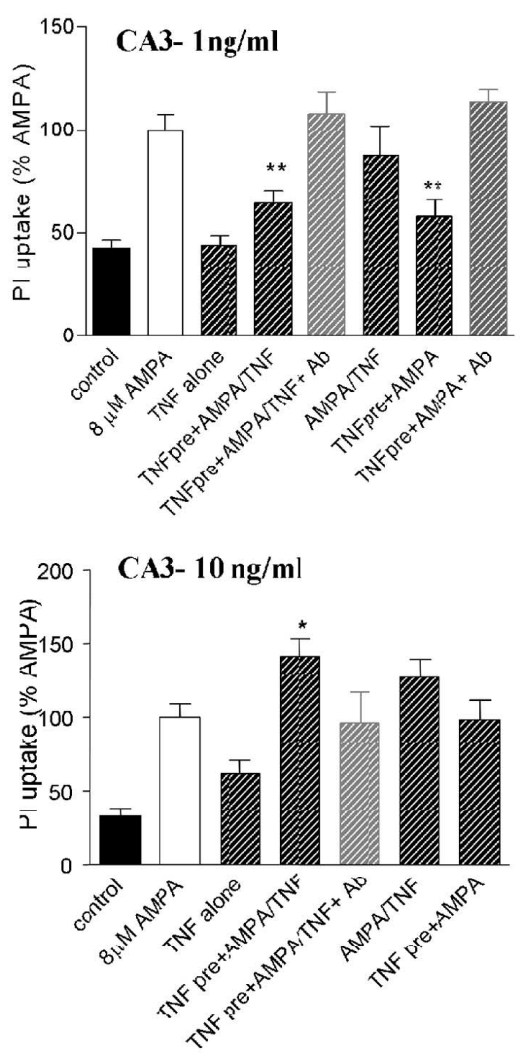

Figure 4. Modulation of AMPA-induced cell death in WT cultured mice hippocampal slices by TNF- $\alpha$. $\boldsymbol{A}$, Effects of $1 \mathrm{ng} / \mathrm{ml}$ TNF- $\alpha$ on PI uptake in CA1 and CA3 pyramidal cell layers $(n=8-41) . B$, Effects of $10 \mathrm{ng} / \mathrm{ml} \mathrm{TNF-} \alpha$ on PI uptake in CA1 and CA3 subfields $(n=9-35)$. In agreement with Figure 1, TNF pre represents preincubation starting at day 0; AMPA and AMPA/TNF represent excitotoxic insult (AMPA) or coexposure of AMPA and TNF- $\alpha$ added at day 1. Data are mean \pm SEM. ${ }^{*} p<0.05,{ }^{* *} p<$ 0.01 , and ${ }^{* * *} p<0.001$ using ANOVA with Bonferroni's correction for comparison with the effect of $8 \mu \mathrm{M}$ AMPA (100\%).

AMPA-induced neuronal cell death when slices were exposed to this cytokine either before or during incubation with AMPA. In addition, $1 \mathrm{ng} / \mathrm{ml}$ human TNF- $\alpha$ did not afford neuroprotection (Fig. 5B).

\section{Selective involvement of TNF- $\alpha$ receptors in the neuronal death and survival pathways}

To dissect the specific and selective involvement of both TNFR in either neuroprotection or exacerbating effects induced by TNF- $\alpha$ on AMPA-induced toxicity, we used hippocampal slice cultures from TNFR1 and/or TNFR2 KO mice.

When TNFR1 KO hippocampal slices were preincubated with $10 \mathrm{ng} / \mathrm{ml}$ mouse recombinant TNF- $\alpha$ for $24 \mathrm{~h}$ followed by coincubation with AMPA, we found that the neurotoxic effect observed in WT slice cultures was absent. However, the neuroprotective effect mediated by $1 \mathrm{ng} / \mathrm{ml}$ TNF- $\alpha$ in WT slices was still observed in TNFR1 KO slices both in CA1 $(72.2 \pm 3.6 ; n=88)$ and in CA3 $(64.5 \pm 7.9 ; n=72)$ subfields (Fig. 6A). When TNFR2 KO hippocampal slice cultures were exposed to $1 \mathrm{ng} / \mathrm{ml}$ mouse recombinant TNF- $\alpha$, the neuroprotective effect was not observed; conversely, the neurotoxic effect mediated by $10 \mathrm{ng} / \mathrm{ml}$ was still apparent both in CA1 $(121.8 \pm 3.6 ; n=36)$ and in CA3 $(134.9 \pm 12.9 ; n=30)$ subfields (Fig. $6 B$ ). Both protective and neurotoxic effects mediated by mouse recombinant TNF- $\alpha$ in WT slice cultures were lost in hippocampal slice cultures from mice lacking both TNF- $\alpha$ receptors (double KO) (Fig. 6C). The neurotoxic effect of AMPA in organotypic slice cultures of TNFR $\mathrm{KO}$ mice was similar to the effect observed in WT slices. 
A

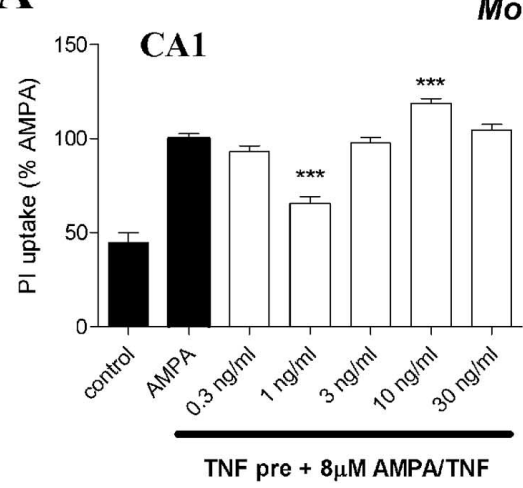

Mouse TNF- $\alpha$

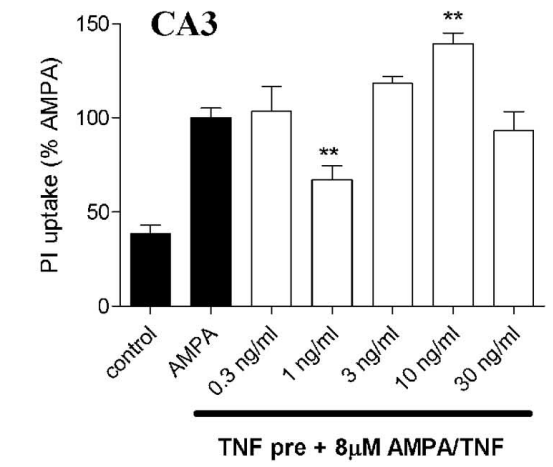

B

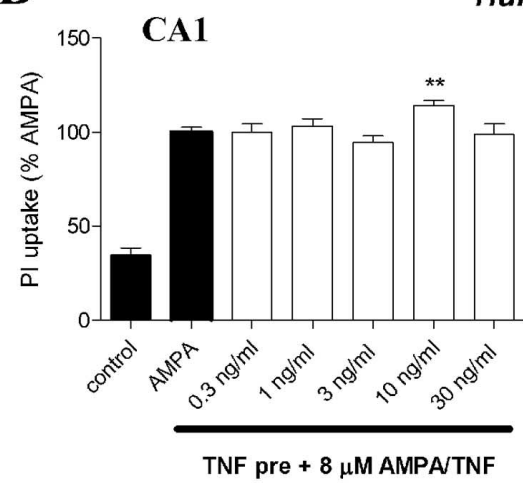

Human TNF- $\alpha$

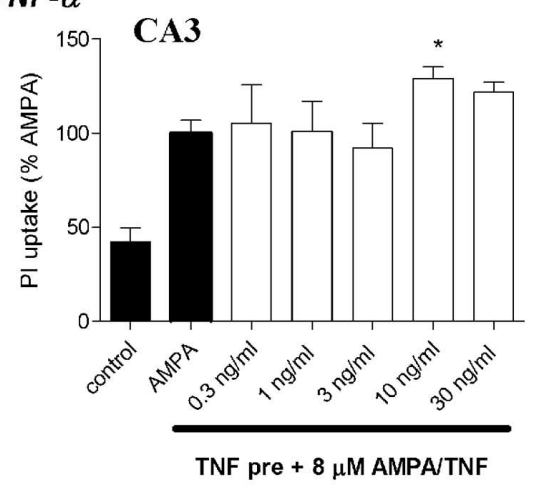

Figure 5. Dose-response relationship for increasing concentrations of mouse $(\boldsymbol{A})$ or human $(\boldsymbol{B})$ TNF- $\alpha(0.3-30 \mathrm{ng} / \mathrm{ml})$ on AMPA-induced PI uptake, measured in CA1 and CA3 subfields of WT cultured mice hippocampal slices. $A$, Effects of mouse TNF- $\alpha$ on Pl uptake in CA1 and CA3 subfields $(n=6-86)$. TNF pre represents preincubation starting at day 0 , and AMPA/TNF represents coexposure of AMPA and TNF- $\alpha$ added at day 1. B, Effects of human TNF- $\alpha$ on PI uptake in CA1 and CA3 subfields $(n=6-29)$. TNF pre represents preincubation starting at day 0 , and AMPA/TNF represents coexposure of AMPA and TNF- $\alpha$ added at day 1. Data are mean \pm SEM. ${ }^{*} p<0.05,{ }^{* *} p<0.01$, and ${ }^{* * *} p<0.001$, using ANOVA with Bonferroni's correction for comparison with the effect of $8 \mu \mathrm{m}$ AMPA set at $100 \%$.

\section{Microglial dynamics in AMPA-induced neuronal cell death}

Double immunohistochemical detection of microglial cells, with $\mathrm{Mac}-1$, and the proliferating cells, labeled by BrdU incorporation, allowed detection of spatial and morphological changes in microglial cells in the slice cultures after exposure to AMPA. The cultures exposed to $8 \mu \mathrm{M}$ AMPA for $24 \mathrm{~h}$ and stained by double immunohistochemistry for Mac-1 expression and BrdU incorporation showed an average increase in the number of Mac-1positive cells of $97.4 \pm 2.3$ cells per culture $(n=19)$ in the CA1 pyramidal cell layer (Fig. $7 A)$ and $51.9 \pm 2.9$ cells per culture $(n=$ 20 ) in the CA3 pyramidal layer (Fig. $7 B$ ) compared with $68.74 \pm$ 2.1 cells $(n=17)$ (Fig. 7A) and 39.2 \pm 2.2 cells $(n=23)$ (Fig. $7 B)$, respectively, in nontreated control cultures. The average number of BrdU-positive cells per culture increased to $43.9 \pm 3.6$ cells per culture $(n=21)$ in the CA1 pyramidal cell layer and $17.5 \pm 1.7$ $(n=20)$ in the CA3 pyramidal cell layer, compared with $16.33 \pm$ 9.3 cells $(n=17)$ and $9.4 \pm 1.2$ cells $(n=23)$, respectively, in control cultures. The number of cells double stained for Mac-1 and BrdU increased to $26.7 \pm 2.8$ cells per culture $(n=21)$ in the CA1 pyramidal cell layer and $12.2 \pm 1.1$ cells per culture $(n=20)$ in the CA3 pyramidal cell layer compared with $10.1 \pm 1.4(n=$ $23)$ and $3.6 \pm 0.7(n=23)$, respectively, in control cultures.

When slices were left to recover for $4 \mathrm{~d}$ after $24 \mathrm{~h}$ of exposure to AMPA, we observed a significant increase in microglia cells labeled with BrdU in the CA1 pyramidal cell layer $(51.2 \pm 2.2$ cells per culture; $n=37$ ) and in the CA3 pyramidal cell layer
$(17.9 \pm 1.3$ cells per culture; $n=33)$ compared with nontreated control cultures $[6.3 \pm 0.85$ cells $(n=43)$ and $3.3 \pm 0.5$ cells $(n=40)$, respectively].

The number of Mac-1-positive cells and double-labeled Mac-1/BrdU-positive cells at $24 \mathrm{~h}$ versus $5 \mathrm{~d}$ (in control and AMPA-treated slices) (Fig. 7) indicate a robust increase in the number of Mac-1positive microglia in the lesion area after $24 \mathrm{~h}$ (suggesting migration of microglia), whereas at $5 \mathrm{~d}$, we found a large increase in double-labeled cells (suggesting proliferation of microglia). This observation may indicate that microglial activation is secondary to cell injury rather than a cause.

The Mac-1-positive microglial cells, BrdU-positive cells, and double-labeled Mac-1-positive and BrdU-positive cells (Fig. 8) specifically accumulated in the lesioned CA1 and CA3 pyramidal cell layers, where the increased PI uptake occurred (Fig. 8A-D). The morphology of the Mac1-positive microglial cells in the lesion areas changed from a typical resting ramified morphology, showing a long and slender process with several thin side branches as observed in untreated control cultures (Fig. $8 E, G$ ) to activated ameboid-like microglial cells in cultures exposed to $8 \mu \mathrm{M}$ AMPA (Fig. $8 F, H$ ). Outside the damaged areas, most of the microglial cells maintained with a ramified shape, characteristic of resting or less-activated cells (Fig. 8F).

\section{Discussion}

We investigated the neurotoxic and neuroprotective effects of IL- $1 \beta$ and TNF- $\alpha$ under excitotoxic activation of the AMPA subtype of glutamate receptors. Hippocampal slice cultures represent an ideal model for studying the functional consequences of changes in cytokine concentrations on neuronal survival during excitotoxic insults. This information is relevant for understanding the role of inflammatory reactions in a variety of neurological disorders and for elucidating under which conditions cytokines have beneficial or detrimental effects on cell survival.

\section{Dose-dependent AMPA-induced cell death in mouse hippocampal slice cultures}

Previous studies, using cellular PI uptake as a marker of neuronal cell death, have characterized the dose-dependent excitotoxic profile of AMPA, kainate, and NMDA in rat hippocampal slice cultures (Kristensen et al., 2001), with half-maximal cell death induced by $3 \mu \mathrm{M}$ AMPA ( $E_{50}$ value) (Silva et al., 2003). Using similar protocols in mouse hippocampal slice cultures, we observed a selective degeneration of neurons in CA1 and CA3 pyramidal cell layers with a $\mathrm{EC}_{50}$ value of $8 \mu \mathrm{M}$ AMPA, which was blocked by LY303070 [( - enantiomer GYKI53655 (( \pm )-1-(4-aminophenyl)-3-methlycarbamyl-4methyl-3,4-dihydro-7,8-methylenedioxy-5H-2,3-benzodiazepine)], a noncompetitive AMPA receptor antagonist (Paternain et al., 1995).

After establishing and standardizing AMPA-mediated lesions in mouse hippocampal slice cultures, we used this system to dem- 
onstrate the existence of dual effects of IL- $1 \beta$ and TNF- $\alpha$ on AMPA excitotoxicity related to the concentration of the cytokine and to the period of tissue exposure. However, it is important to consider that the effective concentrations of cytokines in our system cannot be quantified unequivocally. Several factors contribute to this difficulty, including the binding of cytokines to nonreceptor binding sites, the local release of TNF- $\alpha$ and IL- $1 \beta$ by astrocytes and microglia, and degradation of the cytokines by peptidases. These factors clearly contribute to make very difficult the comparison of the efficiency of cytokines in causing neuronal protection or death in different experimental models.

\section{Effects of IL-1 $\beta$ on AMPA-mediated neuronal death}

We found that IL- $1 \beta$ potentiates AMPA toxicity when slices were exposed to low concentration $(1 \mathrm{ng} / \mathrm{ml})$ of the cytokine and only if IL- $1 \beta$ was present in the medium before and throughout the AMPA exposure. This observation is consistent with previous studies showing that IL- $1 \beta$ can modulate diverse forms of neurodegeneration and seizure activity (Relton and Rothwell, 1992; Vezzani et al., 1999, 2000; Allan and Rothwell, 2001; Dubé et al., 2005) and that low concentrations of IL- $1 \beta$ can enhance hypoxia-induced neuronal death in cultured rat hippocampal slices (Pringle et al., 2001). Regarding possible mechanisms by which low doses of IL- $1 \beta$ increase AMPA excitotoxicity, one possibility may involve the inhibition of astroglial glutamine synthetase (Huang and O'Banion, 1998) or the reduction of astroglial glutamate uptake by a mechanism involving nitric oxide production (Hu et al., 2000). An alternative, but not mutually exclusive, mechanism may involve functional interactions between IL-1R1 and AMPA receptors leading to an increase in inward $\mathrm{Ca}^{2+}$ currents. Previous evidence has shown that IL- $1 \beta$ can increase NMDA receptor function in rat hippocampal neurons by activation of tyrosine kinases, resulting in an increased susceptibility of hippocampal neurons to glutamate-mediated cell loss (Viviani et al., 2003). The data obtained in the present work indicate that the effects of IL- $1 \beta$ are mediated by IL-1R1, because they were inhibited in the presence of IL-1ra.

We found that $10 \mathrm{ng} / \mathrm{ml} \mathrm{IL-} \beta$ induced neuroprotective effects only when IL- $1 \beta$ was present before AMPA incubation, implying that this cytokine can afford beneficial effects on neuronal survival if present for a limited period of time before the insult. We anticipate that this neuroprotection may be attributable to
CA1
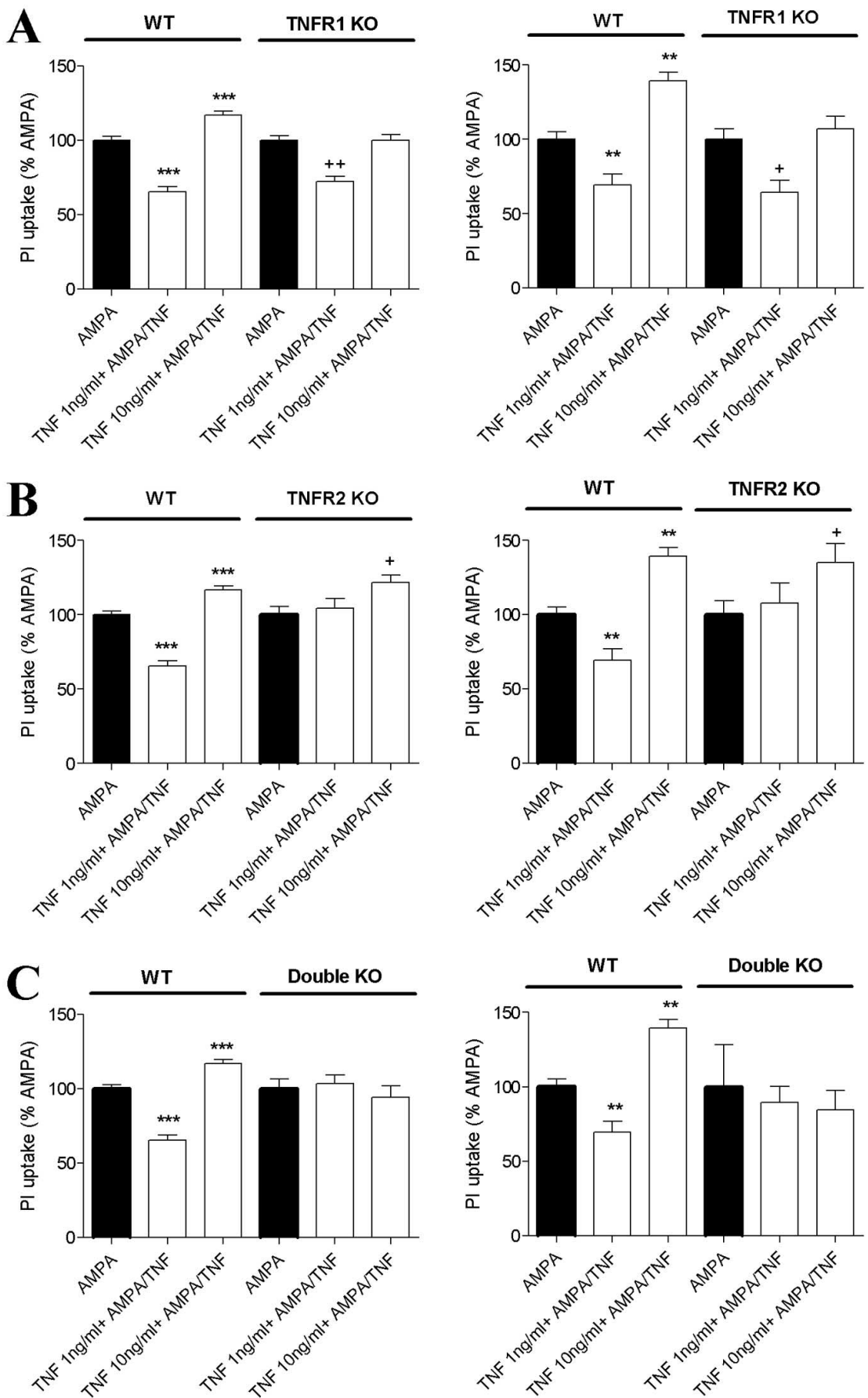

Figure 6. Effects of TNF- $\alpha$ on AMPA-induced cell death in organotypichippocampal slice cultures from WT or KOC57BL/6 mice lacking TNFR1, TNFR2, or both. $A$, Effects of 1 or $10 \mathrm{ng} / \mathrm{ml}$ TNF- $\alpha$ on AMPA-induced Pl uptake in CA1 (left column) and CA3 (right column) subfields ( $n=38$-91) in hippocampal slices of WT or TNFR1 KO. B, Effects of 1 or $10 \mathrm{ng} / \mathrm{ml}$ TNF- $\alpha$ on AMPA-induced Pl uptake in CA1 (left column) and CA3 (right column) subfields ( $n=23-86$ ) in hippocampal slices of WT or TNFR2 K0. C, Effects of 1 or $10 \mathrm{ng} / \mathrm{ml}$ TNF- $\alpha$ on AMPAinduced Pluptake in CA1 (left column) and CA3 (right column) subfields $(n=13-86)$ in hippocampal slices ofWT or double K0 (TNFR1 and TNFR2). Data are mean \pm SEM. ${ }^{* *} p<0.01$ and ${ }^{* * *} p<0.001$ using ANOVA with Bonferroni's correction for comparison with the effect of $8 \mu \mathrm{MAMPA}$ (set at 100\%) in WT slice cultures; ${ }^{+} p<0.05$ and ${ }^{++} p<0.01$ using ANOVA with Bonferroni's correction for comparison with effect of $8 \mu \mathrm{MAMPA}$ (set at 100\%) in the respective $\mathrm{KO}$ slice cultures.

IL-1 $\beta$-dependent transcription of neurotrophic factors (Miyachi et al., 2001), which is compatible with the need of preincubation time to obtain neuroprotection. Accordingly, the biochemical mechanisms underlying the requirement for pre-exposure to the cytokine to obtain neuroprotection were not clearly identified, 

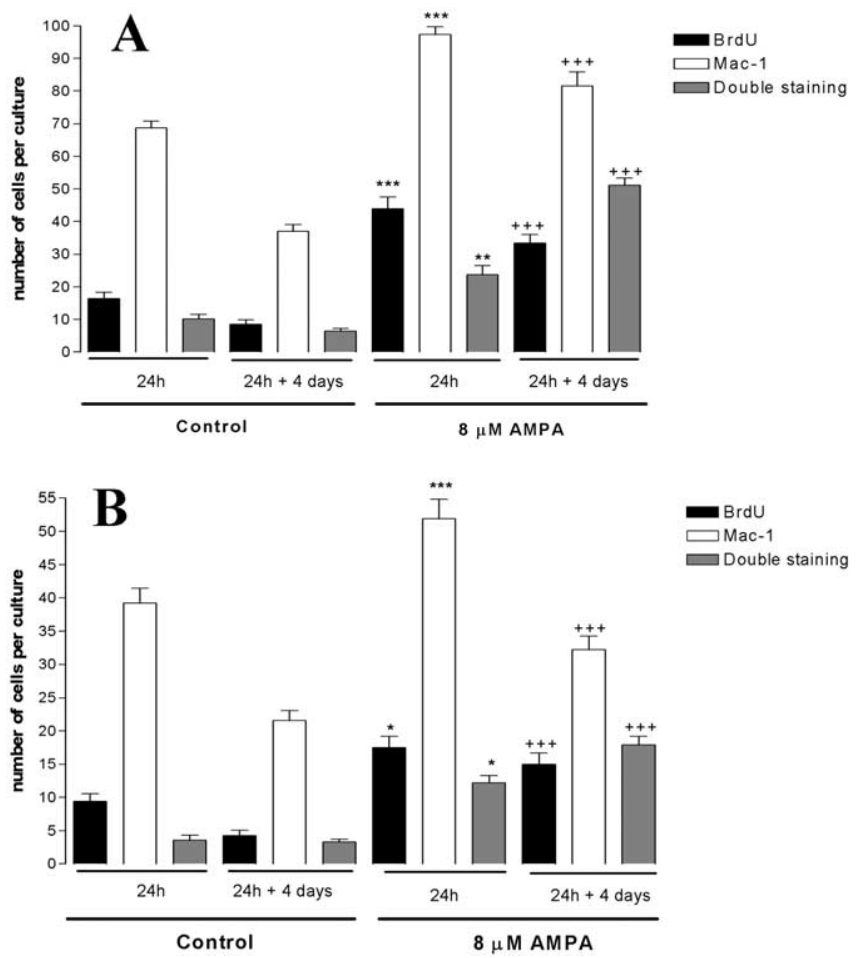

Figure 7. Stereological cell counts of Mac-1-positive microglial cells and BrdU-labeled cells in slice cultures exposed to AMPA. Anti-Mac-1, anti-BrdU, and double anti-Mac-1/anti-BrdUpositive cells were counted in control cultures and in cultures exposed to $8 \mu \mathrm{M}$ AMPA for $24 \mathrm{~h}$ with or without an additional $4 \mathrm{~d}$ of recovery in normal culture medium. Counts were performed in CA1 $(\boldsymbol{A})$ and CA3 $(\boldsymbol{B})$ pyramidal cell layers. Data are expressed as the average number of cells per culture \pm SEM. ${ }^{*} p<0.05 ;{ }^{* *} p<0.01 ;{ }^{* * *} p<0.001$, using ANOVA with Bonferroni's correction for comparison with the average number of cells in control slices exposed to normal medium for $24 \mathrm{~h} ;{ }^{+++} p<0.001$ using ANOVA with Bonferroni's correction for comparison with the average number of cells in control slices exposed to normal medium for $5 \mathrm{~d}$.

but one possibility is that IL- $1 \beta$ can reduce excitatory amino acid-induced neurodegeneration (Carlson et al., 1999) by increasing the production and release of NGF (Strijbos and Rothwell, 1995).

\section{Effects of TNF- $\alpha$ on AMPA-mediated neuronal death}

TNF- $\alpha$ exacerbates AMPA-induced neuronal death at relatively high doses but only if coincubated with the excitotoxin. In addition, high concentrations of TNF- $\alpha$ can, by itself, be neurotoxic. These observations are compatible with previous findings showing that TNF- $\alpha$ potentiates the glutamatergic synaptic strength by increasing the surface expression of AMPA receptors (Beattie et al., 2002; Stellwagen et al., 2005), because this effect may contribute to potentiate neurodegeneration caused by non-NMDA receptor activation. Thus, human NT2-N neuronal cell lines, exposed to $10 \mathrm{ng} / \mathrm{ml} \mathrm{TNF}-\alpha$, showed an increased susceptibility to kainate (Yu et al., 2002), and microinjections of kainate plus TNF- $\alpha$ in the rat spinal cord induced a robust necrotic damage mediated by activation of AMPA receptors (Hermann et al., 2001).

Low doses of TNF- $\alpha$ had a neuroprotective effect on AMPA receptor-mediated excitotoxicity. TNF- $\alpha$ has been demonstrated to play a protective role against ischemia in mice (Nawashiro et al., 1997b) and against amyloid $\beta$-peptide toxicity in rat hippocampal cultures (Barger et al., 1995), when administered before the toxic insults. Neuroprotective effects have also been reported on embryonic rat forebrain neurons against glucose
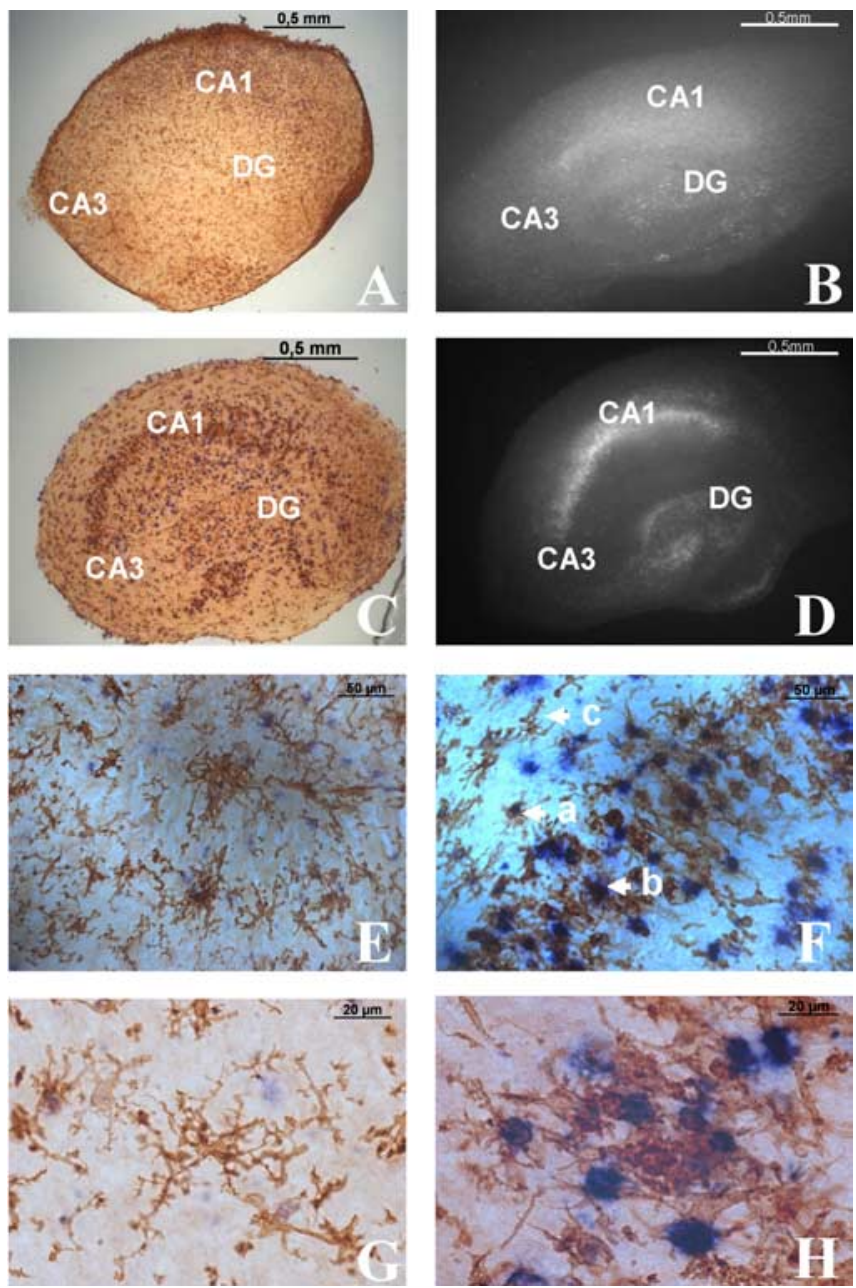

Figure 8. Morphological changes of Mac-1-positive microglial cells from resting to activated state in mouse hippocampal slice cultures exposed to AMPA. $A-D$, Localization of Mac-1/BrdU double staining $(\boldsymbol{A}, \boldsymbol{C})$ and $\mathrm{PI}$ uptake $(\boldsymbol{B}, \boldsymbol{D})$ in control culture $(\boldsymbol{A}, \boldsymbol{B})$ and culture exposed to $8 \mu \mathrm{M}$ AMPA for $24 \mathrm{~h}$, followed by $4 \mathrm{~d}$ of recovery in normal medium $(\boldsymbol{C}, \boldsymbol{D})$. The control cultures $(\boldsymbol{A}, \boldsymbol{B})$ display a random distribution of resting microglia, sporadic BrdU-positive cells $(\boldsymbol{A})$, and lowbasal PI uptake $(\boldsymbol{B})$. Cultures exposed to $8 \mu \mathrm{M} \mathrm{AMPA}(\boldsymbol{C}, \boldsymbol{D})$ display increased numbers of microglia and BrdU-positive cells in the lesion areas ( $C A 1$ and $C A 3 ; C$ ) and a concomitant increase of PI uptake in the same subfields $(\boldsymbol{D})$. $\boldsymbol{E}$, Resting microglia in a control slice culture showing sporadic BrdU-positive cells. G, High-power photomicrograph of microglia stained for anti-Mac-1 located in CA1 pyramidal cell layer. Reactive microglia and an increase in the number of anti-BrdU-positive cells following $8 \mu \mathrm{m}$ AMPA are shown. $\boldsymbol{F}$, a, Double-labeled Mac- 1 and BrdU-positive cell; b, activated Mac-1-positive cell; c, resting-like Mac-1-positive cell. $\boldsymbol{H}$, High-power photomicrograph of labeled anti-BrdU-positive microglial cell located in CA1 pyramidal cell layer.

deprivation and excitatory amino acid toxicity (Cheng et al., 1994). The protective effects of TNF- $\alpha$ may depend on its ability to promote the maintenance of calcium homeostasis by increasing the expression of calbindin (Cheng et al., 1994), to stimulate antioxidant pathways (Barger et al., 1995; Wilde et al., 2000), or to increase transient outward potassium currents (Houzen et al., 1997). Moreover, using mice lacking TNF- $\alpha$ receptors or selective stimulation of TNFR1 by human TNF- $\alpha$, we defined the selective involvement of TNF- $\alpha$ receptor subtypes in the opposite effects of TNF- $\alpha$ on AMPA-induced cell death: namely, the neuroprotection was mediated by TNFR2, whereas the exacerbating action on AMPA toxicity was mediated by TNFR1.

In accordance, other authors showed that TNF- $\alpha$ potentiation of AMPA excitotoxicity likely depends on the activation of an 
intracellular "death domain" coupled to TNFR1 that has been previously shown to contribute to cell death on target cells (Fontaine et al., 2002; Yang et al., 2002). Accordingly, others showed that absence of TNFR1 led to a strong reduction of neurodegeneration in a model of retinal ischemia, whereas lack of TNFR2 led to an enhancement of neurodegeneration, clearly indicating that TNFR1 augments neuronal death, whereas TNFR2 promotes neuroprotection (Fontaine et al., 2002). These two receptors have been recently shown to also mediate distinct actions of TNF- $\alpha$ on neuronal excitability in the mouse hippocampus; in particular, TNFR2 was involved in the anticonvulsant effects of these cytokines on kainate-induced seizures (Balosso et al., 2005).

TNFR2 is suggested to mediate neuronal survival by sustained NF-kB activation (Marchetti et al., 2004). Thus, the mechanisms modulating the expression of these two receptors may determine neuronal responsiveness to TNF- $\alpha$ and the consequences of inflammatory reactions in brain (Beutler and van Huffel, 1994).

\section{Dynamic of microglial cells}

Microglial cells play an essential role in neuroinflammatory responses related to brain injury (Moriguchi et al., 2003). In the resting state, microglial cells display a highly ramified morphology, but after physical or chemical insults, these cells are rapidly activated and change their morphology to amoeboid shape. It is well known that a number of factors are able to activate microglia and stimulate their proliferation (Eskes et al., 2003).

Microglia represent the large majority of proliferating cells in slice cultures after exposure to AMPA or to NMDA (Dehghani et al., 2004). Accordingly, inhibition of microglia in excitotoxic lesioned organotypic cultures of hippocampal slices significantly reduced microglial labeling with BrdU and the release of cytokines and nitric oxide (Dehghani et al., 2004). An increase in microglia reactivity and proliferation close to degenerating neurons was also observed in the brain of kainate-treated rats (Tooyama et al., 2002) and in models of cerebral ischemia (Dempsey et al., 2003).

The morphological feature of microglia observed in the cultured slices used in the present work is very similar to that found in vivo (Czapiga and Colton, 1999). Moreover, our results show that microglia can be rapidly activated in organotypic cultures of mouse hippocampal slices, displaying morphological changes and proliferation in response to AMPA-induced neuronal death. After exposure to AMPA, we observed a marked increase in the numbers of activated amoeboid-shaped microglial cells with short thick processes. These cells were localized preferentially in the pyramidal layers of CA1 and CA3, in close apposition to the damaged and dying neurons. Interestingly, in regions in which we could not identify significant PI uptake after exposure to AMPA, resident microglia remained in a resting or less-activated state. Considering that microglia are one of the main sources of proinflammatory cytokines released in the brain (Kreutzberg, 1996; Hanisch, 2002), our evidence highlights the possibility that microglia activation may be beneficial or deleterious on neuronal survival.

In conclusion, the identification of the molecular and cellular players involved in the neurotoxic or neuroprotective effects of cytokines released by activated microglia, as well as the mechanisms involved in triggering microglia activation, proliferation, and chemotaxis, may contribute to the identification of new pharmacological targets for the prevention of neuronal damage associated with trauma, stroke, and epilepsy and in neurodegenerative diseases.

\section{References}

Allan SM, Rothwell NJ (2001) Cytokines and acute neurodegeneration. Nat Rev Neurosci 2:734-744

Balosso S, Ravizza T, Perego C, Peschon J, Campbell IL, De Simoni MG, Vezzani A (2005) Tumor necrosis factor- $\alpha$ inhibits seizures in mice via p75 receptors. Ann Neurol 57:804-812.

Barger SW, Horster D, Furukawa K, Goodman Y, Krieglstein J, Mattson MP (1995) Tumor necrosis factors alpha and beta protect neurons against amyloid beta-peptide toxicity: evidence for involvement of a kappaBbinding factor and attenuation of peroxide and $\mathrm{Ca}^{2+}$ accumulation. Proc Natl Acad Sci USA 92:9328-9332.

Beattie EC, Stellwagen D, Morishita W, Bresnahan JC, Ha BK, Von Zastrow M, Beattie MS, Malenka RC (2002) Control of synaptic strength by glial TNFalpha. Science 295:2282-2285

Beattie MS (2004) Inflammation and apoptosis: linked therapeutic targets in spinal cord injury. Trends Mol Med 10:580-583.

Beutler B, van Huffel C (1994) Unravelling function in the TNF ligand and receptor families. Science 264:667-668.

Bruce AJ, Boling W, Kindy MS, Peschon J, Kraemer PJ, Carpenter MK, Holtsberg FW, Mattson MP (1996) Altered neuronal and microglial responses to excitotoxic and ischemic brain injury in mice lacking TNF receptors. Nat Med 2:788-794.

Carlson NG, Wieggel WA, Chen J, Bacchi A, Rogers SW, Gahring LC (1999) Inflammatory cytokines IL-1 alpha, IL-1 beta, IL-6, and TNF-alpha impart neuroprotection to an excitotoxin through distinct pathways. J Immunol 163:3963-3968.

Cheng B, Christakos S, Mattson MP (1994) Tumor necrosis factors protect neurons against metabolic-excitotoxic insults and promote maintenance of calcium homeostasis. Neuron 12:139-153.

Czapiga M, Colton CA (1999) Function of microglia in organotypic slice cultures. J Neurosci Res 56:644-651.

De A, Krueger JM, Simasko SM (2003) Tumor necrosis factor alpha increases cytosolic calcium responses to AMPA and $\mathrm{KCl}$ in primary cultures of rat hippocampal neurons. Brain Res 981:133-142.

Dehghani F, Conrad A, Kohl A, Korf H-W, Hailer NP (2004) Clodronate inhibits the secretion of proinflammatory cytokines and NO by isolated microglial cells and reduces the number of proliferating glial cells in excitotoxically injured organotypic hippocampal slice cultures. Exp Neurol 189:241-251.

Dempsey RJ, Sailor KA, Bowen KK, Tureyen K, Vemuganti R (2003) Strokeinduced progenitor cell proliferation in adult spontaneously hypertensive rat brain: effect of exogenous IGF-1 and GDNF. J Neurochem 87:586-597.

De Simoni MG, Perego C, Ravizza T, Moneta D, Conti M, Marchesi F, De Luigi A, Garattini S, Vezzani A (2000) Inflammatory cytokines and related genes are induced in the rat hippocampus by limbic status epilepticus. Eur J Neurosci 12:2623-2633.

Downen M, Amaral TD, Hua LL, Zhao ML, Lee SC (1999) Neuronal death in cytokine-activated primary human brain cell culture: role of tumor necrosis factor-alpha. Glia 28:114-127.

Dubé C, Vezzani A, Behrens M, Bartfai T, Baram TZ (2005) Interleukinlbeta contributes to the generation of experimental febrile seizures. Ann Neurol 57:152-155.

Eskes C, Juillerat-Jeanneret L, Leuba G, Honegger P, Monnet-Tschudi F (2003) Involvement of microglia-neuron interactions in the tumor necrosis factor- $\alpha$ release, microglia activation, and neurodegeneration induced by trimethyltin. J Neurosci Res 71:583-590.

Fontaine V, Mohand-Said S, Hanoteau N, Fuchs C, Pfizenmaier K, Eisel U (2002) Neurodegenerative and neuroprotective effects of tumor necrosis factor (TNF) in retinal ischemia: opposite roles of TNF receptor 1 and TNF receptor 2. J Neurosci 22:RC216(1-7).

Gabellec MM, Griffais R, Fillion G, Haour F (1995) Expression of interleukin 1 alpha, interleukin 1 beta and interleukin-1 receptor antagonist mRNA in mouse brain: regulation by bacterial lipopolysaccharide (LPS) treatment. Mol Brain Res 31:122-130.

Gary DS, Bruce-Keller AJ, Kindy MS, Mattson MP (1998) Ischemic and excitotoxic brain injury is enhanced in mice lacking the p55 tumor necrosis factor receptor. J Cereb Blood Flow Metab 18:1283-1287.

Hanisch UK (2002) Microglia as a source and target of cytokines. Glia 40:140-155.

Hara H, Friedlander RM, Gagliardini V, Ayata C, Fink K, Huang Z, ShimizuSasamata M, Yuan J, Moskowitz MA (1997) Inhibition of interleukin 
1beta converting enzyme family proteases reduces ischemic and excitotoxic neuronal damage. Proc Natl Acad Sci USA 94:2007-2012.

Hermann GE, Rogers RC, Bresnahan JC, Beattie MS (2001) Tumor necrosis factor-alpha induces cFOS and strongly potentiates glutamate-mediated cell death in the rat spinal cord. Neurobiol Dis 8:590-599.

Houzen H, Kikuchi S, Kanno M, Shinpo K, Tashiro K (1997) Tumor necrosis factor enhancement of transient outward potassium currents in cultured rat cortical neurons. J Neurosci Res 50:990-999.

Hsu SS, Newell DW, Tucker A, Malouf AT, Winn HR (1994) Adenosinergic modulation of CA1 neuronal tolerance to glucose deprivation in organotypic hippocampal cultures. Neurosci Lett 178:189-192.

Hu S, Sheng WS, Ehrlich LC, Peterson PK, Chao CC (2000) Cytokine effects on glutamate uptake by human astrocytes. Neuroimmunomodulation 7:153-159.

Huang TL, O'Banion MK (1998) Interleukin-1 beta and tumor necrosis factor-alpha suppress dexamethasone induction of glutamine synthetase in primary mouse astrocytes. J Neurochem 71:1436-1442.

Kreutzberg GW (1996) Microglia: a sensor for pathological events in the CNS. Trends Neurosci 19:312-318.

Kristensen BW, Noraberg J, Jakobsen B, Gramsbergen JB, Ebert B, Zimmer J (1999) Excitotoxic effects of non-NMDA receptor agonist in organotypic corticostriatal slice cultures. Brain Res 841:143-159.

Kristensen BW, Noraberg J, Zimmer J (2001) Comparation of excitotoxic profiles of ATPA, AMPA, KA and NMDA in organotypic hippocampal slice cultures. Brain Res 917:21-44.

Kunkler PE, Hulse RE, Kraig RP (2004) Multiplexed cytokine protein expression profiles from spreading depression in hippocampal organotypic cultures. J Cereb Blood Flow Metab 24:829-839.

Loddick SA, Rothwell NJ (1996) Neuroprotective effects of human recombinant interleukin-1 receptor antagonist in focal cerebral ischaemia in the rat. J Cereb Blood Flow Metab 16:932-940.

Loddick SA, MacKenzie A, Rothwell NJ (1996) An ICE inhibitor, z-VADDCB attenuates ischaemic brain damage in the rat. NeuroReport 7:1465-1468.

Marchetti L, Klein M, Schlett K, Pfizenmaier K, Eisel UL (2004) Tumor necrosis factor (TNF)-mediated neuroprotection against glutamateinduced excitotoxicity is enhanced by $N$-methyl-D-aspartate receptor activation. Essential role of a TNF receptor 2-mediated phosphatidylinositol 3-kinase-dependent NF-kappa B pathway. J Biol Chem 30:32869-32881.

Marquette C, Van Dam AM, Ceccaldi PE, Weber P, Haour F, Tsiang H (1996) Induction of immunoreactive interleukin-1 beta and tumor necrosis factor-alpha in the brain of rabies virus infected rats. J Neuroimmunol 68:45-51.

Mattson MP, Barger SW, Furukawa K, Bruce AJ, Wyss-Coray T, Mark RJ, Mucke L (1997) Cellular signalling roles of TGF beta, TNF alpha and beta APP in brain injury responses and Alzheimer's disease. Brain Res Rev 23:47-61.

Meistrell ME, Botchkina GI, Wang H, Di Santo E, Cockroft KM, Bloom O, Vishnubhakat JM, Chezzi P, Tracey KJ (1997) Tumor necrosis factor is a brain damaging cytokine in cerebral ischemia. Shock 8:341-348.

Minami M, Kuraishi Y, Yamaguchi T, Nakai S, Hirai Y, Satoh M (1990) Convulsants induce interleukin-1 beta messenger RNA in rat brain. Biochem Biophys Res Commun 171:832-837.

Minami M, Kuraishi Y, Satoh M (1991) Effects of kainic acid on mRNA levels of IL-1beta, IL-6, TNF alpha and LIF in the rat brain. Biochem Biophys Res Commun 176:593-598.

Minami M, Kuraishi K, Yabuuchi K, Yamazaki K, Satoh M (1992) Induction of interleukin-1 beta mRNA in rat brain after transient forebrain ischemia. J Neurochem 58:390-392.

Miyachi T, Asai K, Tsuiki H, Mizuno H, Yamamoto N, Yokoi T, Aoyama M, Togari H, Wada Y, Miura Y, Kato T (2001) Interleukin-1beta induces the expression of lipocortin 1 mRNA in cultured rat cortical astrocytes. Neurosci Res 40:53-60.

Moriguchi S, Mizoguchi Y, Tomimatsu Y, Hayashi Y, Kadowaki T, Kagamiishi Y, Katsube N, Yamamoto K, Inoue K, Watanabe S, Nabekura J, Nakanishi H (2003) Potentiation of NMDA receptor-mediated synaptic response by microglia. Mol Brain Res 119:160-169.

Nawashiro H, Martin D, Hallenbeck JM (1997a) Neuroprotective effects of TNF binding protein in focal cerebral ischemia. Brain Res 778:265-271.

Nawashiro H, Tasaki K, Ruetzler CA, Hallenbeck JM (1997b) TNF-alpha pretreatment induces protective effects against focal cerebral ischemia in mice. J Cereb Blood Flow Metab 17:483-490.

Noraberg J, Kristensen BW, Zimmer J (1999) Markers for neuronal degeneration in organotypic slice cultures. Brain Res Brain Res Protoc 3:278-290.

Paternain AV, Morales M, Lerma J (1995) Selective antagonism of AMPA receptors unmasks kainate receptor-mediated responses in hippocampal neurons. Neuron 14:185-189.

Perry VH, Hume DA, Gordon S (1985) Immunohistochemical localization of macrophages and microglia in the adult and developing mouse brain. Neuroscience 15:313-326.

Peschon JJ, Torrance DS, Stocking KL, Glaccum MB, Otten C, Willis CR, Charrier K, Morrissey PJ, Ware CB, Mohler KM (1998) TNF receptordeficient mice reveal different roles for p55 and p75 in several models of inflammation. J Immunol 160:943-952.

Pozzo Miller LD, Mahanty NK, Connor JA, Landis DM (1994) Spontaneous pyramidal cell death in organotypic slice cultures from rat hippocampus is prevented by glutamate receptor agonists. Neuroscience 63:471-487.

Pringle AK, Niyadurupola N, Johns P, Anthoni DC, Iannotti F (2001) Interleukin-1 beta exacerbates hypoxia-induced neuronal damage, but attenuates toxicity produced by simulated ischaemia and excitotoxicity in rat organotypic hippocampal slice cultures. Neurosci Lett 305:29-32.

Rivera S, Gold SJ, Gall CM (1994) Interleukin-1 beta increases basic fibroblast growth factor mRNA expression in adult rat brain and organotypic hippocampal cultures. Mol Brain Res 27:12-26.

Relton JK, Rothwell NJ (1992) Interleukin-1 receptor antagonist inhibits ischaemic and excitotoxic neuronal damage in the rat. Brain Res Bull 29:243-246.

Rothwell NJ, Luheshi GN (2000) Interleukin 1 in the brain: biology, pathology and therapeutic target. Trends Neurosci 23:618-625.

Scherbel U, Raghupathi R, Nakamura M, Saatman KE, Trojanowski JQ, Neugebauer E, Marino MW, McIntosh TK (1999) Differential acute and chronic responses of tumor necrosis factor-deficient mice to experimental brain injury. Proc Natl Acad Sci USA 96:8721-8726.

Silva AP, Pinheiro PS, Carvalho AP, Carvalho CM, Jakobsen B, Zimmer J, Malva JO (2003) Activation of neuropeptide Y receptors is neuroprotective against excitotoxicity in organotypic hippocampal slice cultures. FASEB J 17:1118-1120.

Stefferl A, Hopkins SJ, Rothwell NJ, Luheshi GN (1996) The role of TNFalpha in fever: opposing actions of human and murine TNF-alpha and interactions with IL-beta in the rat. Br J Pharmacol 118:1919-1924.

Stellwagen D, Beattie EC, Seo JY, Malenka RC (2005) Differential regulation of AMPA receptor and GABA receptor trafficking by tumor necrosis factor-alpha. J Neurosci 25:3219-3228.

Stoppini L, Buchs PA, Muller D (1991) A simple method for organotypic cultures of nervous tissue. J Neurosci Methods 37:173-182.

Strijbos PJ, Rothwell NJ (1995) Interleukin-1 beta attenuates excitatory amino acid-induced neurodegeneration in vitro: involvement of nerve growth factor. J Neurosci 15:3468-3474.

Sullivan PG, Bruce-Keller AJ, Rabchevsky AG, Christakos S, Clair DK, Mattson MP, Scheff SW (1999) Exacerbation of damage and altered NF- $\kappa$ B activation in mice lacking tumor necrosis factor receptors after traumatic brain injury. J Neurosci 19:6248-6256.

Tartaglia LA, Weber RF, Figari IS, Reynolds C, Palladino Jr MA, Goeddel DV (1991) The two different receptors for tumor necrosis factor mediate distinct cellular responses. Proc Natl Acad Sci USA 88:9292-9296.

Taupin V, Toulmond S, Serrano A, Benavides J, Zavala F (1993) Increase in IL-6, IL-1 and TNF levels in rat brain following traumatic lesion. Influence of pre- and post-traumatic treatment with Ro5 4864, a peripheraltype ( $\mathrm{p}$ site) benzodiazepine ligand. J Neuroimmunol 42:177-185.

Tooyama I, Bellier JP, Park M, Minnasch P, Uemura S, Hisano T, Iwami M, Aimi Y, Yasuhara O, Kimura H (2002) Morphologic study of neuronal death, glial activation, and progenitor cell division in the hippocampus of rat models of epilepsy. Epilepsia 43:39-43.

Vezzani A, Conti M, De Luigi A, Ravizza T, Moneta D, Marchesi F, De Simoni MG (1999) Interleukin-1 $\beta$ immunoreactivity and microglia are enhanced in the rat hippocampus by focal kainate application: functional evidence for enhancement of electrographic seizures. J Neurosci 19:5054-5065.

Vezzani A, Moneta D, Conti M, Richichi C, Ravizza T, De Luigi A, De Simoni MG, Sperk G, Andell-Jonsson S, Lundkvist J, Iverfeldt K, Bartfai T (2000) Powerful anticonvulsant action of IL-1 receptor antagonist on intracere- 
bral injection and astrocytic overexpression in mice. Proc Natl Acad Sci USA 97:11534-11539.

Viviani B, Bartesaghi S, Gardoni F, Vezzani A, Behrens MM, Bartfai T, Binaglia M, Corsini E, Di Luca M, Galli CL, Marinovich M (2003) Interleukin- $1 \beta$ enhances NMDA receptor-mediated intracellular calcium increase through activation of the Src family of kinases. J Neurosci 23:8692-8700.

Vornov JJ, Tasker RC, Coyle JT (1991) Direct observation of the agonistspecific regional vulnerability to glutamate, NMDA, and kainate neurotoxicity in organotypic hippocampal cultures. Exp Neurol 114:11-22.

Wang X, Yue TL, Barone FC, White RF, Gagnon RC, Feuerstein GZ (1994) Concomitant cortical expression of TNF-alpha and IL-1 beta mRNAs follows early response gene expression in transient focal ischemia. Mol Chem Neuropathol 23:103-114.

Wang X, Barone FC, Aiyar NY, Feuerstein GZ (1997) Interleukin-1 receptor and receptor antagonist gene expression after focal stroke in rats. Stroke $28: 155-161$.

West MJ (1999) Stereological methods for estimating the total number of neurons and synapses: issues of precision and bias. Trends Neurosci 22:51-61.

Wilde GJ, Pringle AK, Sundstrom LE, Mann DA, Iannoyyi F (2000) Atten- uation and augmentation of ischaemia-related neuronal damage by tumor necrosis factor-alpha in vitro. Eur J Neurosci 12:3863-3870.

Wolvers DA, Marquette C, Berkenbosch F, Haour F (1993) Tumor necrosis factor-alpha: specific binding sites in rodent brain and pituitary gland. Eur Cytokine Netw 4:377-381.

Yabuuchi K, Minami M, Katsumata S, Satoh M (1993) In situ hybridization study of interleukin-1 beta mRNA induced by kainic acid in the rat brain. Mol Brain Res 20:153-161.

Yang L, Lindholm K, Konishi Y, Li R, Shen Y (2002) Target depletion of distinct tumor necrosis factor receptor subtypes reveals hippocampal neuron death and survival through different signal transduction pathways. J Neurosci 22:3025-3032.

Yu Z, Cheng G, Wen X, Wu GD, Lee WT, Pleasure D (2002) Tumor necrosis factor alpha increases neuronal vulnerability to excitotoxic necrosis by inducing expression of the AMPA-glutamate receptor subunit GluR1 via an acid sphingomyelinase- and NF-kappaB-dependent mechanism. Neurobiol Dis 11:199-213.

Zimmermann C, Ginis I, Furuya K, Klimanis D, Ruetzler C, Spatz M, Hallenbeck JM (2001) Lipopolysaccharide-induced ischemic tolerance is associated with increased levels of ceramide in brain and in plasma. Brain Res 895:59-65. 